\title{
Electrical conductivity testing of corn seeds as influenced by temperature and period of storage
}

\author{
Simone Aparecida Fessel(1), Roberval Daiton Vieira(1), Mara Cristina Pessoa da Cruz ${ }^{(2)}$, \\ Rinaldo Cesar de Paula(1) and Maristela Panobianco(1)
}

(1)Universidade Estadual Paulista (Unesp), Dep. de Produção Vegetal, CEP 14884-900 Jaboticabal, SP, Brazil. E-mail: sifessel@ig.com.br, rdvieira@fcav.unesp.br, rcpaula@fcav.unesp.br, maris-pa@uol.com.br (2)Unesp, Dep.de Solos e Adubos. E-mail: mcpcruz@fcav.unesp.br

\begin{abstract}
The objective of this work was to evaluate the effects of temperature $\left(10,20,30,20 / 10\right.$ and $\left.30 / 10^{\circ} \mathrm{C}\right)$ and period of storage on electrical conductivity (EC) in four seed lots of corn (Zea mays L.), as well as the mineral composition of the soaking solution. EC test determines indirectly the integrity of seed membrane systems, and is used for the assessment of seed vigor, because this test detects the seed deterioration process since its early phase. The research comprised determinations of water content, germination, accelerated aging (AA), cold (CT) and $\mathrm{EC}$ vigor tests, and determinations of $\mathrm{Ca}^{2+}, \mathrm{Mg}^{2+}$ and $\mathrm{K}^{+}$release to the solution, after seed soaking of four corn seed lots. The evaluations were performed each four months during a period of 16 months. For statistical analysis, a completely randomized split plot design was used with eight replications. Except for seed lots stored at $10^{\circ} \mathrm{C}$, all vigor evaluations revealed a decline in vigor, but AA and CT showed more sensitiveness to declines of seed physiological quality than EC. Potassium was the main leached ion regardless of the storage temperature.
\end{abstract}

Index terms: Zea mays, vigor, seed leachates, potassium.

\section{Teste de condutividade elétrica em sementes de milho armazenadas sob diferentes temperaturas e períodos}

\begin{abstract}
Resumo - O objetivo deste estudo foi verificar o efeito da temperatura $\left(10,20,30,20 / 10\right.$ e 30/10 $\left.{ }^{\circ} \mathrm{C}\right)$ e do período de armazenamento, sobre os resultados do teste de condutividade elétrica e, também, sobre a composição mineral da solução de embebição de quatro lotes de sementes de milho. O teste de condutividade elétrica baseiase na integridade do sistema de membranas celulares, e é usado para a determinação do vigor de sementes, pois permite detectar as primeiras manifestações do processo de deterioração. Foram determinados: o teor de água das sementes, a germinação, vigor (testes de envelhecimento acelerado, de frio e de condutividade elétrica) e os conteúdos de $\mathrm{Ca}^{2+}, \mathrm{Mg}^{2+}$ e $\mathrm{K}^{+}$na solução de embebição das sementes, usada para determinar a condutividade elétrica. Para a análise estatística foi usado o delineamento inteiramente casualizado, em esquema de parcelas subdivididas, com oito repetições. Com exceção do armazenamento a $10^{\circ} \mathrm{C}$, todas as avaliações revelaram redução no vigor das sementes, porém os testes de envelhecimento acelerado e de frio mostraram maior sensibilidade aos declínios da qualidade fisiológica da semente do que o teste de condutividade elétrica. $\mathrm{O} \mathrm{K}$ foi o ion lixiviado em maior quantidade, independentemente da temperatura de armazenamento.
\end{abstract}

Termos para indexação: Zea mays, vigor, liberação de exsudatos, potássio

\section{Introduction}

The electrical conductivity (EC) and the accelerated aging (AA) tests are valid to assess seed vigor of pea and soybean, respectively (Association of Official Seed Analysts, 2002). Although these tests are internationally standardized for these two species, they continue to require adjustments of methodology for application to other species; their efficiency in determining seed vigor of other species also needs additional research (Marcos-Filho, 1998).

The EC is based on the fact that seeds, when soaked in water, exude ions, sugars and other metabolites, from the starting of the soaking period, due to changes in the integrity of the cell membranes, as a function of water amount and of the level of seed deterioration. In deteriorated seeds, the repair mechanism is absent or inefficient, or the membranes are completely damaged 
(Bewley \& Black, 1985), thus permitting leaching of larger electrolyte amounts.

Although EC test results are reproducible among laboratories, some factors affect the results, such as seed size (Tao, 1978; Deswal \& Sheoran, 1993), soaking temperature (Murphy \& Noland, 1982), soaking period (Loeffler et al., 1988; Schmidt \& Tracy, 1989), initial water content (Tao, 1978; Loeffler et al., 1988; Vieira et al., 2002), and the presence of physical damaged seeds (Tao, 1978; Duke \& Kakefuda, 1981). However, all these factors can be controlled to minimize their effects. Besides, there is another group of factors which can not be easily controlled, such as the effect of genotype (Short \& Lacy, 1976; Panobianco \& Vieira, 1996), seed developmental stage at harvesting (Styer \& Cantliffe, 1983; Powell, 1986) and storage conditions (Ferguson, 1988; Vieira et al., 2001). Studies on soybean seeds have shown that the results of the EC test may be influenced by storage temperature, especially low temperatures such as $10^{\circ} \mathrm{C}$ (Ferguson, 1988; Vieira et al., 2001).

EC test results have demonstrated a desirable efficiency to indicate seed performance to establish the stand under a wide range of field conditions, as reported for soybean seeds (Colete et al., 2004; Vieira et al., 2004), as well as an important vigor test for this specie (Vieira et al., 1999a, 1999b). Gotardo et al. (2001) also showed that this test can be used to assess corn seed vigor.

The objective of this work was to evaluate the effects of temperature and period of storage on the EC results for corn seeds, and on the mineral composition of the seed soaking solution used for the EC readings.

\section{Material and Methods}

The experiment was conducted in the Laboratory of Seed Analysis, Unesp, Campus of Jaboticabal, SP, Brazil. Four corn seed samples were used, representing the hybrids D657 and D769, submitted or not to commercial chemical treatment
[160 g Captan 50WP (captan) +50 mLActelic $50 \mathrm{EC}$ (pirimifos-methyl) $+50 \mathrm{~mL} \mathrm{~K}$-Obiol $250 \mathrm{SC}$ (deltamethrin) $+2 \mathrm{~mL}$ nonionic surfactant Agral $+40 \mathrm{~mL}$ colorific per $100 \mathrm{~kg}$ of seeds], obtained from Dow AgroSciences Seed Co., 1998/1999 harvest, 22 L sieve.

Preliminary evaluations of the seed physiological potential comprised tests on: seed water content (WC), germination (SG), vigor [cold test (CT), accelerated aging (AA), and electrical conductivity (EC)], and the mineral composition $\left(\mathrm{Ca}^{2+}, \mathrm{Mg}^{2+}\right.$ and $\mathrm{K}^{+}$) of the soaking solution. Seed samples were placed in glass containers, closed with lids, and stored as follows: at $10^{\circ} \mathrm{C}, 20^{\circ} \mathrm{C}$ and $30^{\circ} \mathrm{C}$ in cold room; at $20^{\circ} \mathrm{C}$ and $30^{\circ} \mathrm{C}$ in germination chamber for eight months, then stored at $10^{\circ} \mathrm{C}$ for eight months. Seed storage was from May 1999 to September 2000. For treatments at $20^{\circ} \mathrm{C}$ and $30^{\circ} \mathrm{C}$, seeds were moved to $10^{\circ} \mathrm{C}$ on January 2000.

Seeds were sampled, packaged, stored and removed according to the five temperature treatments, period of storage and evaluations. On a period of sexteen months, seeds were tested each four months for the parameters: WC, SG, CT, AA, $\mathrm{EC}$, and mineral composition of the soaking solution. WC was determined by the oven method at $105 \pm 3^{\circ} \mathrm{C}$ for 72 hours, with four replicates, with 25 seeds per treatment (Woltz \& TeKrony, 2001); seed WC was expressed on a seed fresh weight basis. Germination (SG) was tested in eight replicates, with 50 seeds per treatment sown on rolls of paper moistened with water in the proportion 3:1 (water weight:dry paper weight), kept in a germination chamber at $25^{\circ} \mathrm{C}$; normal seedlings were assessed according to International Seed Testing Association (1999). Accelerated aging test (AA) was conducted with eight replicates of 50 seeds each (Hampton \& TeKrony, 1995). Seeds were aged in plastic germination boxes $(11 \times 11 \times 3.5 \mathrm{~cm})$ containing $40 \mathrm{~mL}$ deionized water, and spread as a single layer on a net to avoid contact with water. After 72 hours of aging 
at $45^{\circ} \mathrm{C}$ (Hampton \& TeKrony, 1995; Fessel et al., 2000; Dutra \& Vieira, 2004), in an AA chamber (water jacketed chamber), seed water content and percent germination were determined. Cold test (CT) was carried out with eight replicates of 50 seeds each per treatment sown in plastic boxes $(26 \times 16 \times 9 \mathrm{~cm})$, containing as substrate a mixture of sand and soil (2:1) from an area of a previous corn crop. Water was added until $70 \%$ of water hold capacity of the substrate was achieved. The boxes were covered and placed in a cold room $\left(10^{\circ} \mathrm{C}\right)$ for seven days; next, they were removed, uncovered and kept in the laboratory at temperature varying from 25 to $30^{\circ} \mathrm{C}$ for five days, when normal seedlings were evaluated and counted (International Seed Testing Association, 1999; Association of Official Seed Analysts, 2002).

Electrical conductivity test was carried out with eight replicates of 50 seeds each, weighed $0.01 \mathrm{~g}$, and soaked in plastic cups $(200 \mathrm{~mL})$ containing $75 \mathrm{~mL}$ deionized water for 24 hours at $25^{\circ} \mathrm{C}$ (Vieira \& Krzyzanowski, 1999; Association of Official Seed Analysts, 2002). After soaking, EC was determined in a conductivity meter (Analyser 600) with an electrode with constant 1 .

After the EC reading, mineral composition was evaluated through the filtration of the seed soaking solution of each replicate (rapid filtering, filter Whatman $\mathrm{n}$. 1) for the determination of $\mathrm{K}^{+}$content by flame photometry, and $\mathrm{Ca}^{2+}$ and $\mathrm{Mg}^{2+}$ contents by atomic absorption spectrophotometry (Bataglia et al., 1983; Tomé Junior, 1997).

For statistical analysis, a completely randomized split plot design with eight replicates was used, with storage temperatures $\left(10,20,30,20 / 10\right.$ and $\left.30 / 10^{\circ} \mathrm{C}\right)$ and chemical treatment representing the plots. The subplots were represented by assessment periods during storage.

\section{Results and Discussion}

Results of the preliminary tests carried out at the starting of seed storage period (Table 1) showed that seed water content ranged from 11.3 to $12.8 \%$. The lots used also showed at least $97 \%$ germination, i.e., above the minimum standard established ( $85 \%$ ) for certified corn seeds in Brazil. On this basis, for lots with similar germinability, the identification of differences in physiological potential has become the basic objective for vigor tests (Marcos-Filho, 1998).

Initial cold test results ranged from 87 to $95 \%$, but no standard values have been proposed for their interpretation. The high germination after accelerated aging (AA) and low electrical conductivity (EC) results (Table 1) also suggested that these lots should be considered as high seed vigor. Using AA, Woltz $\&$ TeKrony (2001) reported that lots of high quality should show at least 70 or $80 \%$ germination after the accelerated aging test, as a minimum acceptable level. This indicates that seed lots assessed in the present experiment were above the minimum suggested values (Table 1).

Small variations in water content (WC) were observed during subsequent storage, but this parameter did not show a consistent tendency and was within limits that did not negatively influence the results. Mean moisture was $13.2 \%$ for the D657 hybrid, ranging from 11.8 to $14.4 \%$, and $12.3 \%$ for the D769 hybrid, ranging from 10.5 to $13.7 \%$.

Table 1. Water content (WC) before and after seed ageing, germination (SG), vigor (cold test - CT, accelerated aging - AA, electrical conductivity - EC), and calcium $\left(\mathrm{Ca}^{2+}\right)$, magnesium $\left(\mathrm{Mg}^{2+}\right)$ and potassium $\left(\mathrm{K}^{+}\right)$contents in soaked water of corn seeds, as a preliminary evaluation of seed quality.

\begin{tabular}{|c|c|c|c|c|c|c|c|c|c|c|}
\hline \multirow[t]{2}{*}{ Hybrid } & \multirow{2}{*}{$\begin{array}{c}\text { Seed } \\
\text { treatment }\end{array}$} & \multicolumn{2}{|c|}{$\mathrm{WC}$} & \multirow[t]{2}{*}{$\mathrm{SG}$} & \multicolumn{3}{|c|}{ Vigor } & \multicolumn{3}{|c|}{ Content } \\
\hline & & Before & After AA & & $\mathrm{CT}$ & $\mathrm{AA}$ & $\mathrm{EC}$ & $\mathrm{Ca}^{2+}$ & $\mathrm{Mg}^{2+}$ & $\mathrm{K}^{+}$ \\
\hline & & ------- & ----------- & )--- & ---- & $\begin{array}{l}----- \\
--1\end{array}$ & $\left(\mu \mathrm{S} \mathrm{cm}^{-1} \mathrm{~g}^{-1}\right)$ & -------- & $-(\mathrm{mg} \mathrm{k}$ & 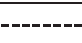 \\
\hline D657 & Treated & 12.8 & 23.8 & 99 & 87 & 97 & 14 & 2.4 & 2.8 & 266.1 \\
\hline D657 & Not treated & 11.8 & 23.8 & 98 & 88 & 94 & 14 & 2.2 & 3.1 & 279.2 \\
\hline D769 & Treated & 11.9 & 24.1 & 99 & 95 & 93 & 10 & 2.5 & 2.1 & 188.8 \\
\hline D769 & Not treated & 11.3 & 23.9 & 97 & 92 & 95 & 10 & 2.4 & 2.4 & 205.4 \\
\hline
\end{tabular}


The seeds of the D657 hybrid stored at 10,20 and $20 / 10^{\circ} \mathrm{C}$ practically showed little change in germination during storage (Figure 1), regardless of seed with chemical treatment. At the same temperatures, similar results were observed for stored seeds of hybrid D769 without chemical treatment, whereas treated seeds had higher germination at $10^{\circ} \mathrm{C}$ over a period of 16 months. In contrast, when all seeds of D657 and not treated seeds of D769 were stored at $30^{\circ} \mathrm{C}$ and $30 / 10^{\circ} \mathrm{C}$, a significant loss in germination occurred during storage. This reduction on seed germination can be attributed to the more stressful conditions in storage at high temperature such as 30 and $30 / 10^{\circ} \mathrm{C}$.

Seed vigor, as assessed by AA test (Figure 2 ) and the cold test (CT) (Figure 3) decreased after four months,
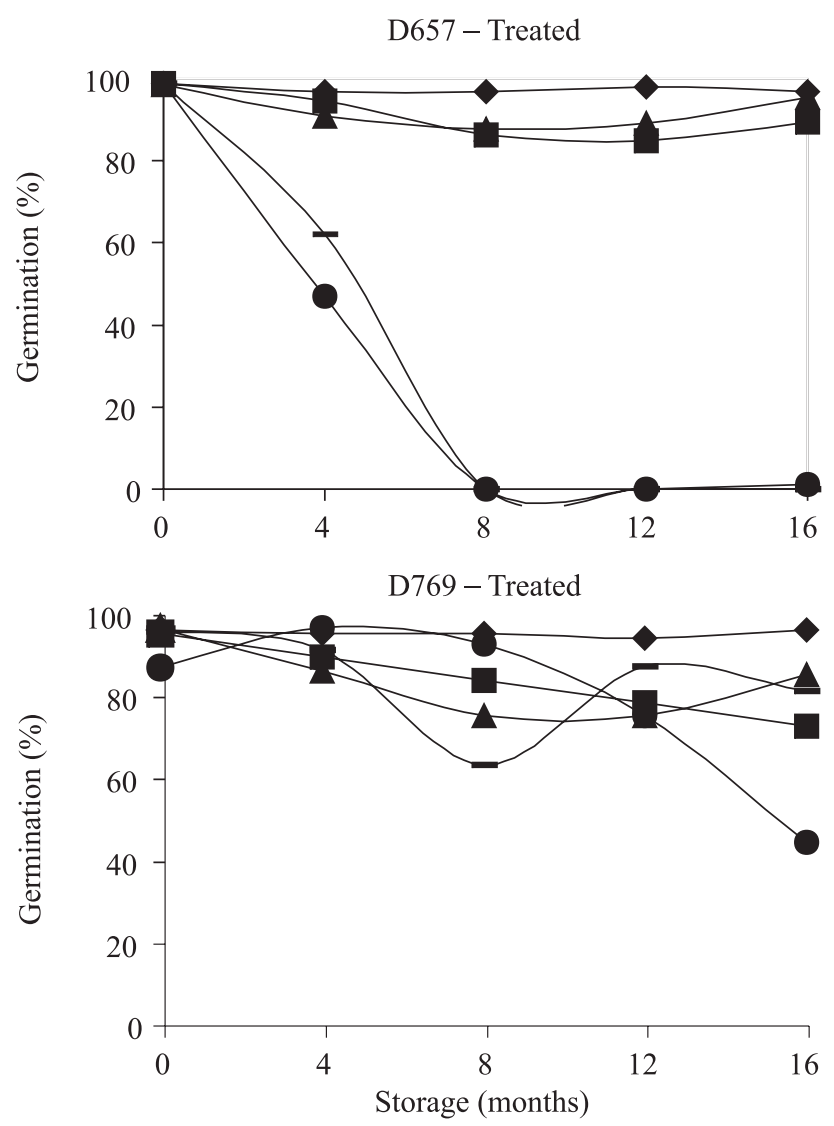

at all storage temperatures, except for $10^{\circ} \mathrm{C}$. Seeds of the two hybrids stored at $10^{\circ} \mathrm{C}$ (Figure 2) had only a small reduction in germination after $\mathrm{AA}$, no decrease in vigor throughout storage, whereas significant reductions were observed at all other temperatures evaluated. Similarly, for CT (Figure 3), only D657 hybrid seeds stored at $10^{\circ} \mathrm{C}$ kept a high vigor, whereas under other storage temperatures seed vigor continued to decrease over time, even at $20^{\circ} \mathrm{C}$ and $20 / 10^{\circ} \mathrm{C}$ where germination remained higher. For D769 hybrid, vigor assessed by the $\mathrm{CT}$ presented the same behavior as vigor tested by AA, with seeds exhibiting small reductions (not significantly) in germinability, when stored at $10^{\circ} \mathrm{C}$ and significant reductions when stored at higher temperatures.
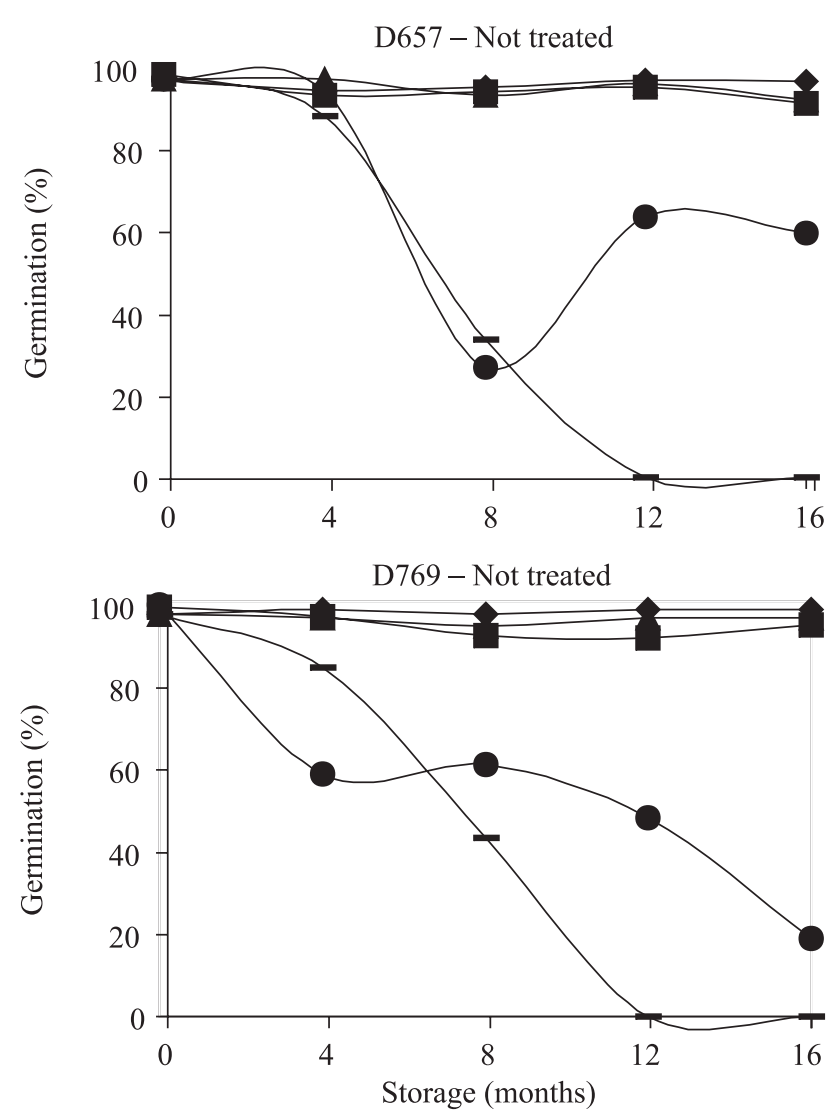

$$
\neg-10^{\circ} \mathrm{C} \rightarrow 200^{\circ} \mathrm{C} \longrightarrow 20 / 10^{\circ} \mathrm{C} \quad-30^{\circ} \mathrm{C} \quad \longrightarrow 30 / 10^{\circ} \mathrm{C}
$$

Figure 1. Germination of corn seeds, hybrids D657 and D769, treated or not, influenced by the period and temperature of storage. 
Similarly to AA and CT, the EC (Figure 4) test did not show decreases in vigor of seed samples stored at $10^{\circ} \mathrm{C}$. However, under higher storage temperatures, the EC increased during storage, with less intensity where the changes in temperature were evaluated. The EC for hybrid D769 was $10 \mu \mathrm{S} \mathrm{cm}^{-1} \mathrm{~g}^{-1}$, in seeds with and without chemical treatment, during preliminary evaluations (Table 1), and at the end of storage at $10^{\circ} \mathrm{C}$ (16 months) EC was 11.6 to $10.2 \mu \mathrm{S} \mathrm{cm}^{-1} \mathrm{~g}^{-1}$. Small changes in conductivity were also observed for the D657 hybrid at $10^{\circ} \mathrm{C}$. The EC increased significantly in seeds stored at $30^{\circ} \mathrm{C}$ and $30 / 10^{\circ} \mathrm{C}$, with a reduction in the level of seed vigor before they were transferred to $10^{\circ} \mathrm{C}$; after transfer, there was a small increase in $\mathrm{EC}$ while seeds were stored at $10^{\circ} \mathrm{C}$.
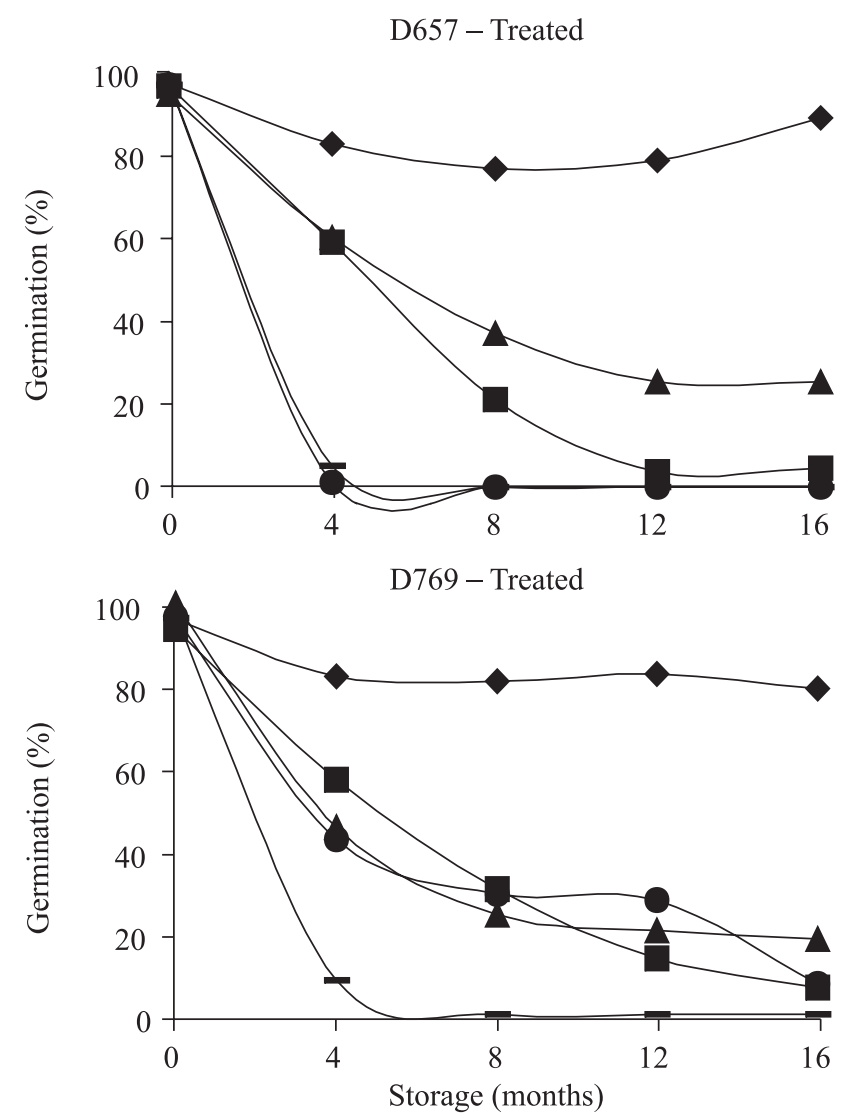

Working with soybean seeds, Vieira et al. (2001) mentioned that membranes also stabilized for seeds stored at $10^{\circ} \mathrm{C}$, resulting in no increase in conductivity. This can raise some questions. Why should seeds stored at $10^{\circ} \mathrm{C}$ apparently stabilize membranes more than seeds stored at $30^{\circ} \mathrm{C}$, for instance, resulting in lower value of EC? According to Bernal-Lugo \& Leopold (1998), the transition from a period of relative membrane stability to dynamic seed aging could occur through a loss of the glassy state. This loss could be influenced by an increase in the water content, in temperature, or by a separation of sugars involved. Besides, the beginning of deterioration could result from a gradual hydrolysis of the soluble sugars. The hydrolysis of sugars presented in seeds would lead to an accumulation of reducing
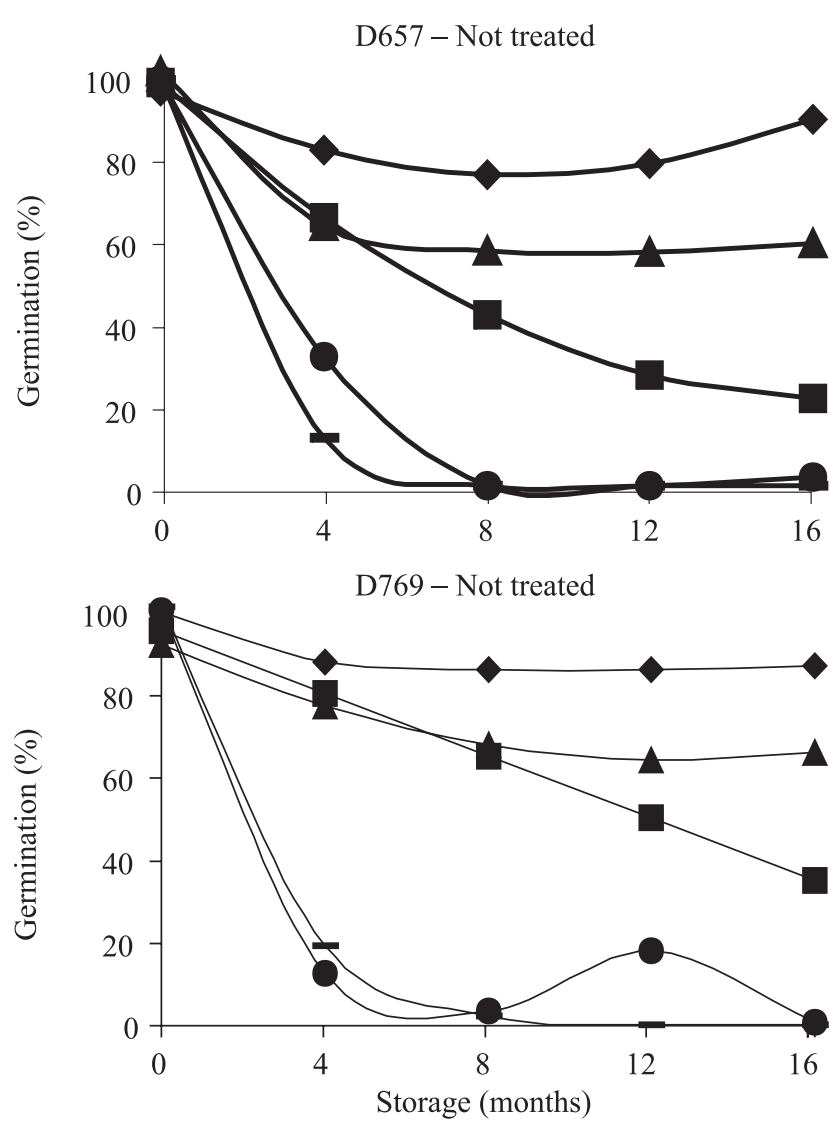

\section{$\longrightarrow 10^{\circ} \mathrm{C} \quad-200^{\circ} \mathrm{C} \longrightarrow 20 / 10^{\circ} \mathrm{C} \quad-30^{\circ} \mathrm{C} \quad \longrightarrow 30 / 10^{\circ} \mathrm{C}$}

Figure 2. Corn seed vigor evaluated through the accelerated aging test (hybrids D657 and D769, treated or not), influenced by the period and temperature of storage. 
sugars which would finally threaten the proteins integrity as a result of the formation of Maillard products (Sun \& Leopold, 1995). However, one or more of the above factors may be involved in the lack of response in EC, when seeds were stored at $10^{\circ} \mathrm{C}$.

The amounts of $\mathrm{Ca}^{2+}, \mathrm{Mg}^{2+}$ and $\mathrm{K}^{+}$ions leached to the soaking solution increased with storage time (Figure 5) for hybrid D657. The amount of $\mathrm{Mg}^{2+}$ leached at 10,20 and $20 / 10^{\circ} \mathrm{C}$ had a very small increase during storage, which was much more evident at 30 and $30 / 10^{\circ} \mathrm{C}$, especially after eight months of storage. The released $\mathrm{K}^{+}$content was higher in seeds stored at high temperatures (30 and $30 / 10^{\circ} \mathrm{C}$ ). When seeds both with and without
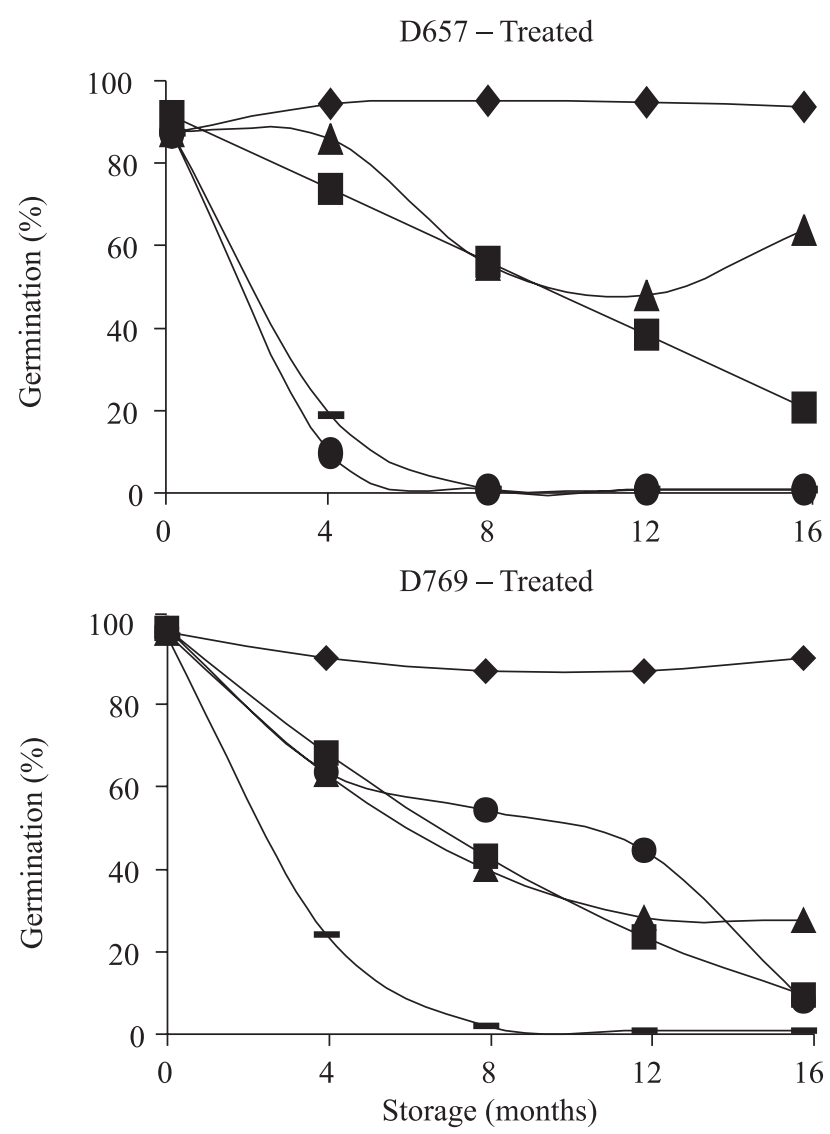

chemical treatment were transferred from the storage temperature to a $10^{\circ} \mathrm{C}$ environment, the increase in $\mathrm{K}^{+}$leakage was lower than that determined in seeds kept at $30^{\circ} \mathrm{C}$. Seeds stored at $10^{\circ} \mathrm{C}$ did not show variation in leachates at 16 months of storage. Similar trend was observed for D769 hybrid .

The overall analysis of the results obtained with corn seeds shows that the decrease in seed vigor was directly proportional to the increased leakage of $\mathrm{Ca}$, $\mathrm{Mg}$ and $\mathrm{K}$ ions, confirming a close relationship of membrane integrity and loss of vigor. The association between reduced vigor and ion leakage, particularly $\mathrm{K}^{+}$, has been studied, and the evaluation of the amount of $\mathrm{K}^{+}$leachates has been proposed as a vigor test for
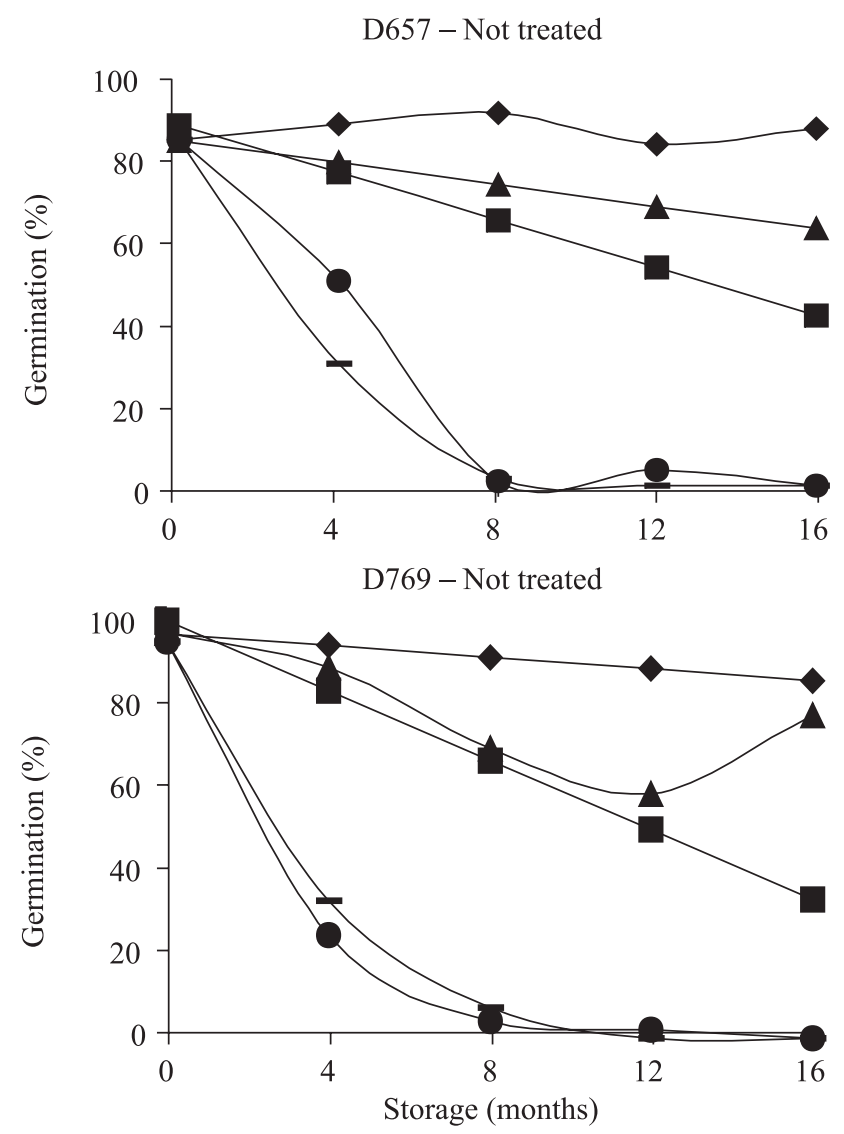

\section{$\longrightarrow 10^{\circ} \mathrm{C} \quad \longrightarrow 20^{\circ} \mathrm{C} \quad \longrightarrow 20 / 10^{\circ} \mathrm{C} \quad \longrightarrow 30^{\circ} \mathrm{C} \quad \longrightarrow 30 / 10^{\circ} \mathrm{C}$}

Figure 3. Corn seed vigor evaluated through cold test (hybrids D657 and D769, treated or not), influenced by the period and temperature of storage. 
soybean seeds (Dias et al., 1995; Custódio \& MarcosFilho, 1997). As emphasized from the present results, the quantity and intensity of leached material are influenced by seed age and physiological condition. The $\mathrm{K}$ ion presented the higher amount of leachates into the imbibing solution. It seems that this ion is the most important or influent on the electrical conductivity results.

Changes in the vigor of corn seeds during storage at $20,30,20 / 10$ and $30 / 10^{\circ} \mathrm{C}$ were more clearly revealed by AA and $\mathrm{CT}$, than they were by EC. In contrast, none of the tests showed any reduction in vigor during $10^{\circ} \mathrm{C}$ storage. This may indicate that during storage at $10^{\circ} \mathrm{C}$ deterioration had not proceeded to the point at which vigor declines.
Ferguson (1988) found that when AA germination of soybean seeds was reduced in seeds stored at $10^{\circ} \mathrm{C}$, EC showed only a small change. More recently, Vieira et al. (2001), also studying soybean seeds, obtained results similar to those of Ferguson (1988) and questioned the use of the EC test to determine seed vigor after storage at low temperatures, especially those close to or lower than $10^{\circ} \mathrm{C}$. In the absence of deterioration of corn seed at $10^{\circ} \mathrm{C}$, the present work neither agrees nor disagrees with this thought. The increased loss of $\mathrm{K}^{+}$in aged seeds, observed at all temperatures, suggested that this might provide an alternative means of evaluating changes in vigor, as it was already suggested for soybean seeds (Dias et al., 1995).
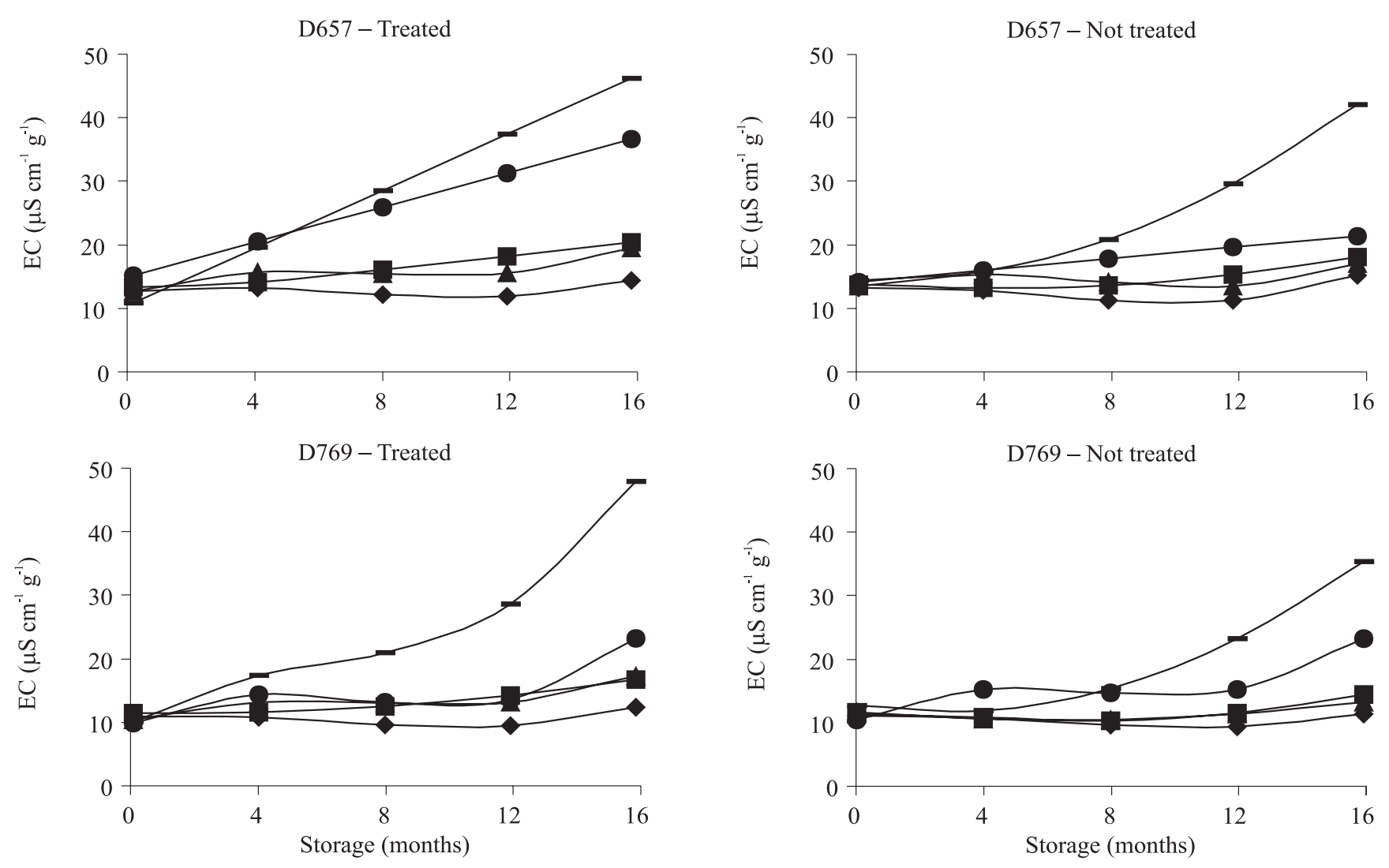

$\neg 10^{\circ} \mathrm{C} \rightarrow 20^{\circ} \mathrm{C} \longrightarrow 20 / 10^{\circ} \mathrm{C} \quad-30^{\circ} \mathrm{C} \quad \longrightarrow 30 / 10^{\circ} \mathrm{C}$

Figure 4. Corn seed vigor evaluated through electrical conductivity test - EC (hybrids D657 and D769, treated or not), influenced by the period and temperature of storage. 

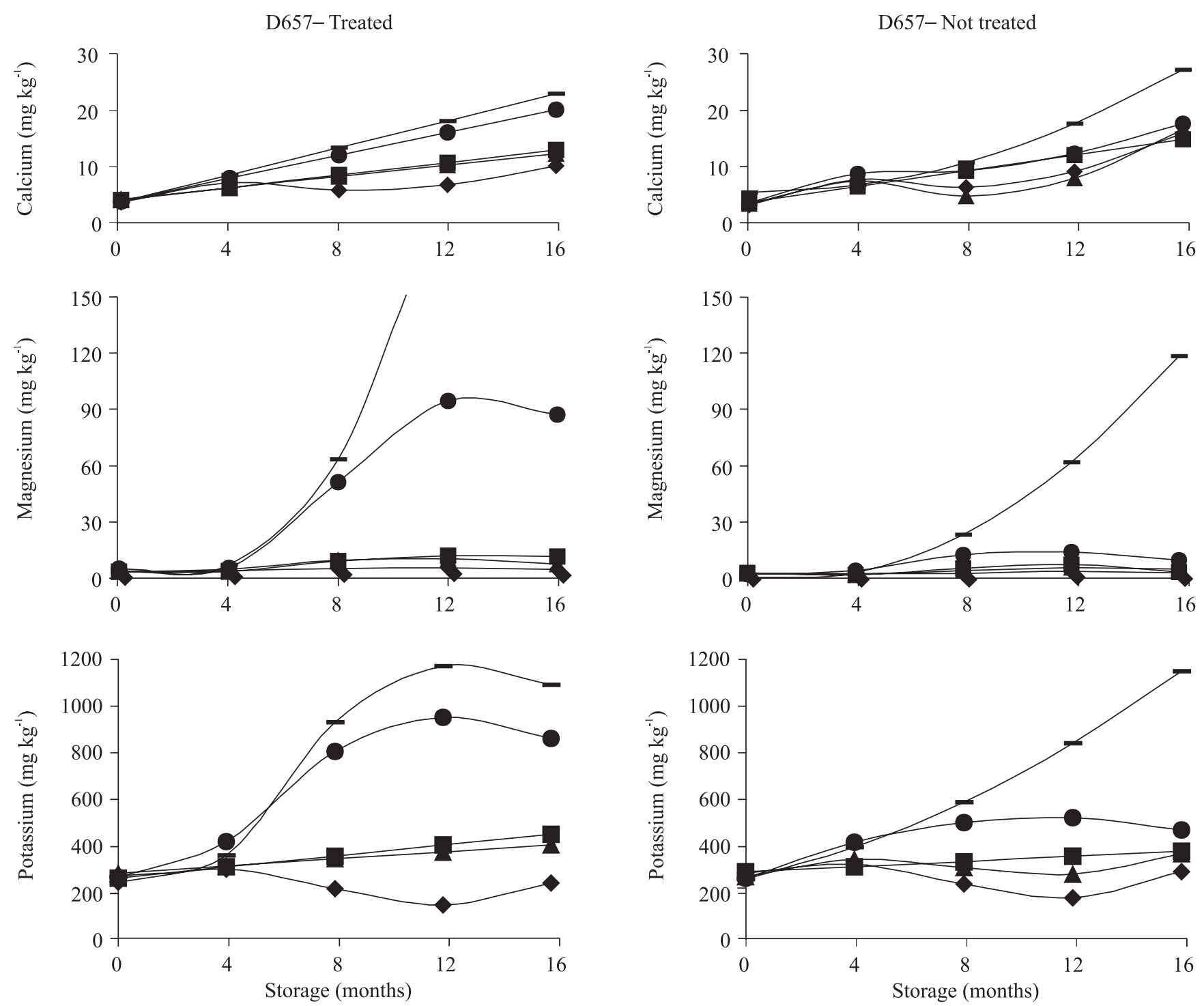

$$
\neg 10^{\circ} \mathrm{C} \longrightarrow 20^{\circ} \mathrm{C} \longrightarrow 20 / 10^{\circ} \mathrm{C} \quad-30^{\circ} \mathrm{C} \longrightarrow 30 / 10^{\circ} \mathrm{C}
$$

Figure 5. Calcium, magnesium and potassium content determined into the imbibition solution for the corn hybrid (D657), treated or not, influenced by the period and temperature of storage.

\section{Conclusions}

1. Electrical conductivity, as vigor test, does notallow to detect seed deterioration in corn seed temperature storage at $10^{\circ} \mathrm{C}$.

2. Potassium is the most important ion to determine the electrical conductivity results.

\section{Acknowledgements}

To Fapesp, for Master's fellowships; to CNPq, for reseach productivity fellowships; to Dow AgroSciences Seed Co., for supplying the seeds. 


\section{References}

ASSOCIATION OF OFFICIAL SEED ANALYSTS. Seed vigor testing handbook. Lincoln, 2002. 105p. (Contribution, 32).

BATAGLIA, O.C.; FURLANI, A.M.C.; TEIXEIRA, J.P.F.; FURLANI, P.R.; GALLO, J.R. Métodos de análise química de plantas. Campinas: Instituto Agronômico, 1983. 48p. (Boletim técnico, 78).

BERNAL-LUGO, I.; LEOPOLD, A.C. The dynamics of seed mortality. Journal of Experimental Botany, v.49, p.1455-1461, 1998.

BEWLEY, J.D.; BLACK, M. Seeds: physiology of development and germination. New York: Plenum Press, 1985. 367p.

COLETE, J.C.F.; VIEIRA, R.D.; DUTRA, A.S. Electrical conductivity and soybean seedling emergence. Scientia Agricola, v.61, p.386-391, 2004.

CUSTÓDIO, C.C.; MARCOS-FILHO, J. Potassium leachate test for the evaluation of soybean seed physiological quality. Seed Science and Technology, v.25, p.549-563, 1997.

DESWAL, D.P.; SHEORAN, I.S. A simple method for seed leakage measurement: applicable to single seeds of any size. Seed Science and Technology, v.21, p.179-185, 1993.

DIAS, D.C.F.S.; MARCOS-FILHO, J.; CARMELO, Q.A.C. Teste de lixiviação de potássio para avaliação do vigor de sementes de soja [Glycine max (L.) Merrill]. Scientia Agricola, v.52, p.444-451, 1995.

DUKE, S.H.; KAKEFUDA, G. Role of the testa in preventing cellular rupture during imbibition of legume seeds. Plant Physiology, v.67, p.449-456, 1981.

DUTRA, A.S.; VIEIRA, R.D. Envelhecimento acelerado como teste de vigor para sementes de milho e soja. Ciência Rural, v.34, p.715721, 2004.

FERGUSON, J.M. Metabolic and biochemical changes during the early stages of soybean seed deterioration. 1988. 138p. Thesis (Ph.D.) - University of Kentucky, Lexington.

FESSEL, S.A.; RODRIGUES, T. de J.D.; FAGIOLI, M.; VIEIRA, R.D. Temperatura e período de exposição no teste de envelhecimento acelerado em sementes de milho. Revista Brasileira de Sementes, v.22, p.163-170, 2000.

GOTARDO, M.; VIEIRA, R.D.; PEREIRA, L.M.A. Teste de condutividade elétrica em sementes de milho. Revista Ceres, v.48, p.333-340, 2001.

HAMPTON, J.G.; TEKRONY, D.M. Handbook of vigour test methods. $3^{\text {rd }}$ ed. Zürich: Ista, 1995. $117 \mathrm{p}$.

INTERNATIONAL SEED TESTING ASSOCIATION. International rules for seed testing. Seed Science and Technology, v.27, p.1-333, 1999. Supplement.

LOEFFLER, T.M.; TEKRONY, D.M.; EGLI, D.B. The bulk conductivity test as an indicator of soybean seed quality. Journal of Seed Technology, v.12, p.37-53, 1988.

MARCOS-FILHO, J. New approaches to seed vigor testing. Scientia Agricola, v.55, p.27-33, 1998.
MURPHY, J.B.; NOLAND, T.L. Temperature effects on seed imbibition and leakage mediated by viscosity and membranes. Plant Physiology, v.69, p.428-431, 1982.

PANOBIANCO, M.; VIEIRA, R.D. Electrical conductivity of soybean soaked seeds. I. Effect of genotype. Pesquisa Agropecuária Brasileira, v.31, p.621-627, 1996.

POWELL, A.A. Cell membranes and seed leachate conductivity in relation to the quality of seed for sowing. Journal of Seed Technology, v.10, p.81-100, 1986.

SCHMIDT, D.H.; TRACY, W.F. Duration of imbibition affects seed leachate conductivity in sweet corn. HortScience, v.24, p.346-347, 1989.

SHORT, G.E.; LACY, M.L. Carbohydrate exudation from pea seeds: effect of cultivar, seed age, seed color, and temperature. Phytopathology, v.66, p.182-187, 1976.

STYER, R.C.; CANTLIFFE, D.J. Changes in seed structure and composition during development and their effects on leakage in two endosperm mutants of sweet corn. Journal of the American Society for Horticultural Science, v.108, p.721-728, 1983.

SUN, W.Q.; LEOPOLD, A.C. The Maillard reaction and oxidative stress during aging of soybean seeds. Physiologia Plantarum, v.94, p.94-104, 1995.

TAO, J.K. Factors causing variations in the conductivity test for soybean seeds. Journal of Seed Technology, v.3, p.10-18, 1978.

TOMÉ JUNIOR, J.B. Manual para interpretação de análise de solo. Guaíba: Agropecuária, 1997. 247p.

VIEIRA, R.D.; KRZYZANOWSKI, F.C. Teste de condutividade elétrica. In: KRZYZANOWSKI, F.C.; VIEIRA, R.D.; FRANÇA NETO, J.B. (Ed.). Vigor de sementes: conceitos e testes. Londrina: Abrates, 1999. p.1-26.

VIEIRA, R.D.; PAIVA-AGUERO, J.A.; PERECIN, D. Electrical conductivity and field performance of soybean seeds. Seed Technology, v.21, p.15-24, 1999a.

VIEIRA，R.D.; PAIVA-AGUERO, J.A.; PERECIN，D.; BITTENCOURT, S.R.M. de. Correlation of electrical conductivity and other vigor tests with field emergence of soybean seedlings. Seed Science and Technology, v.27, p.67-75, 1999b.

VIEIRA, R.D.; PENARIOL, A.L.; PERECIN, D.; PANOBIANCO, M. Condutividade elétrica e teor de água inicial das sementes de soja. Pesquisa Agropecuária Brasileira, v.37, p.1333-1338, 2002.

VIEIRA, R.D.; SCAPPA NETO, A.; BITTENCOURT, S.R.M. de; PANOBIANCO, M. Electrical conductivity of the seed soaking solution and soybean seedling emergence. Scientia Agricola, v.61, p.164-168, 2004.

VIEIRA, R.D.; TEKRONY, D.M.; EGLI, D.B.; RUCKER, M. Electrical conductivity of soybean seeds after storage in several environments. Seed Science and Technology, v.29, p.599-608, 2001.

WOLTZ, J.M.; TEKRONY, D.M. Accelerated aging test for corn seed. Seed Technology, v.23, p.21-34, 2001. 